\title{
Creating a Standardized Watersheds Database for the Lower Rio Grande/ Río Bravo, Texas
}

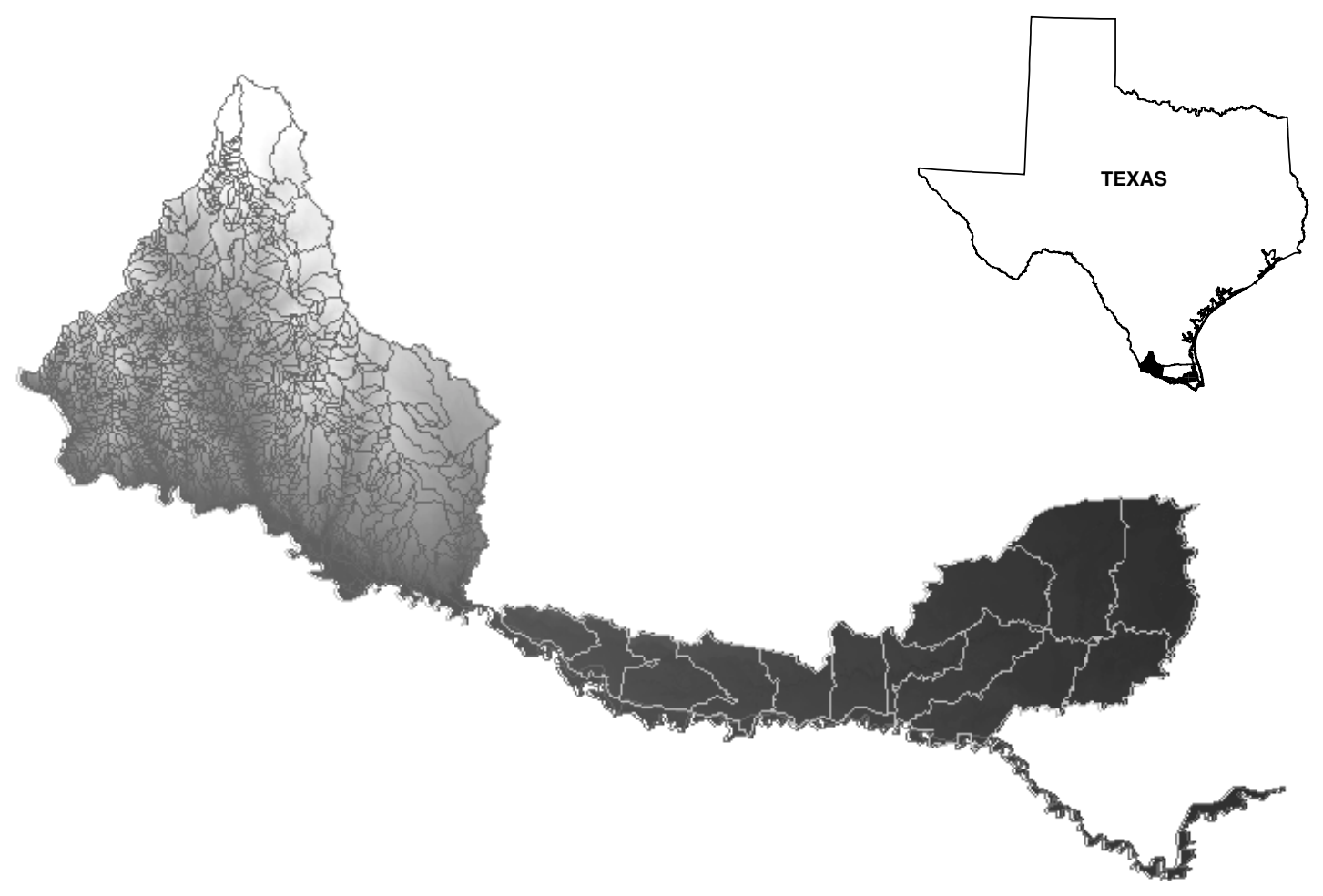

U.S. Department of the Interior U.S. Geological Survey 
U.S. Department of the Interior

U.S. Geological Survey

\section{Creating a Standardized Watersheds Database for the Lower Rio Grande/ Río Bravo, Texas}

By Julie R. Brown, Randy L. Ulery, and Jean W. Parcher

\section{U.S. GEOLOGICAL SURVEY}

Open-File Report 00-065

In cooperation with the Texas Natural Resource Conservation Commission

Austin, Texas

2000 


\section{U.S. DEPARTMENT OF THE INTERIOR}

Bruce Babbitt, Secretary

\section{U.S. GEOLOGICAL SURVEY}

Charles G. Groat, Director

Any use of trade, product, or firm names is for descriptive purposes only and does not imply endorsement by the U.S. Government.

For additional information write to

\section{District Chief}

U.S. Geological Survey

8027 Exchange Dr.

Austin, TX 78754-4733

E-mail: dc_tx@usgs.gov

Copies of this report can be purchased from

U.S. Geological Survey

Branch of Information Services

Box 25286

Denver, CO 80225-0286

E-mail: infoservices@usgs.gov 


\section{CONTENTS}

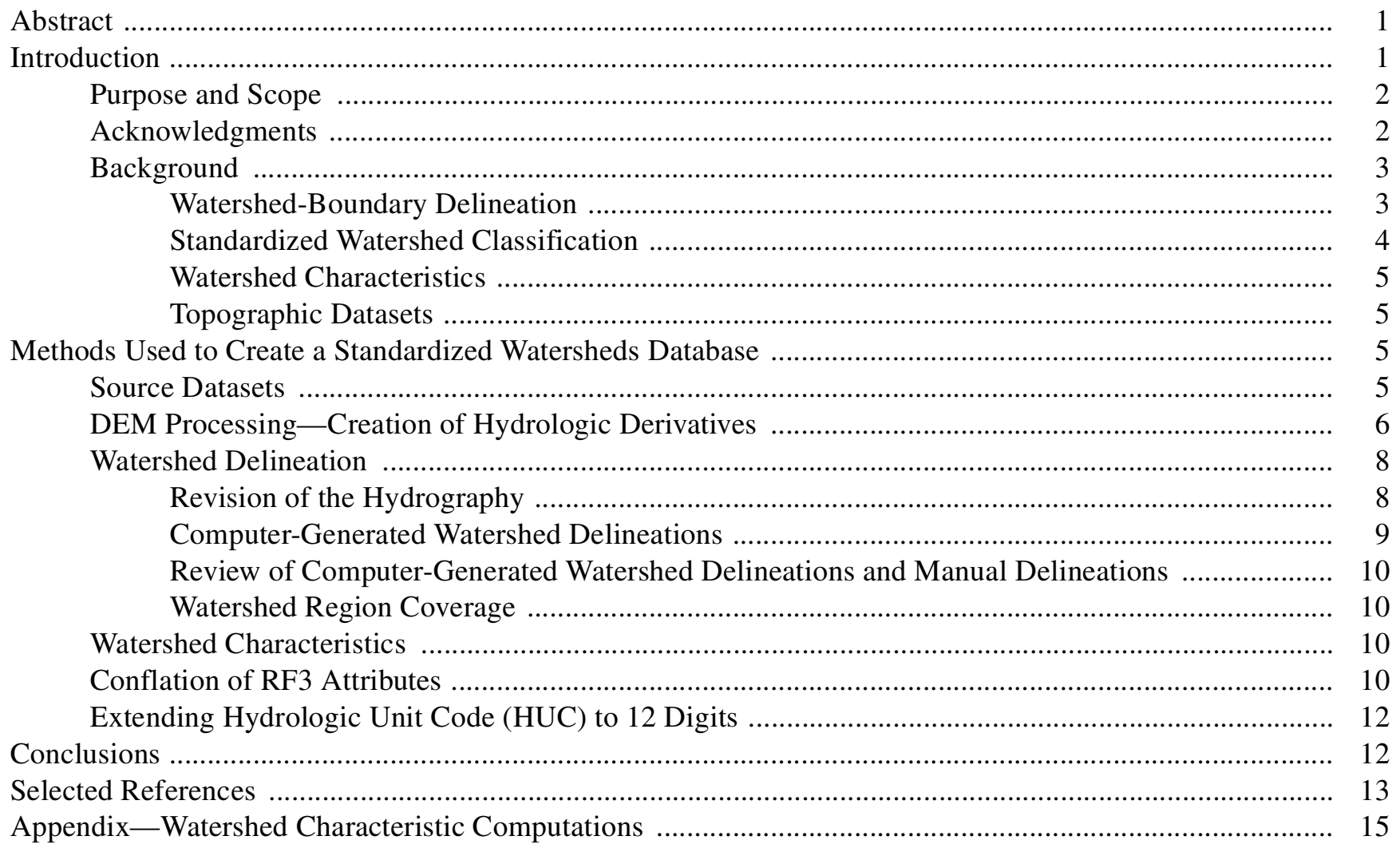

\section{FIGURES}

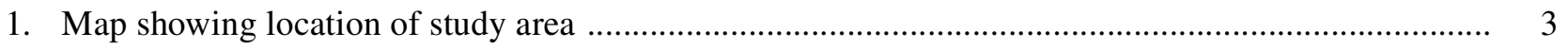

2-4. Diagrams showing:

2. Flow-direction grid

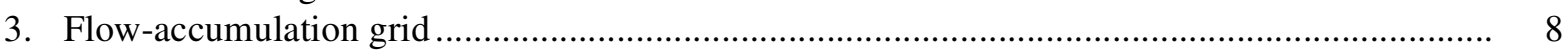

4. Stream network derived from flow-accumulation grid ….................................................... 9

\section{TABLE}

1. Watershed characteristics or classification codes

\section{ACRONYMS}

\author{
AML -Arc Macro Language \\ CIR - Color infrared \\ CRP - Clean Rivers Program \\ DEM - Digital elevation model \\ DLG - Digital line graph \\ DOQ - Digital orthophoto quadrangle \\ EPA - U.S. Environmental Protection Agency \\ ESRI - Environmental Systems Research Institute \\ FGDC - Federal Geographic Data Committee \\ HUC - Hydrologic Unit Code \\ NAWQA - National Water-Quality Assessment
}

\author{
NED - National Elevation Database \\ NHD - National Hydrography Dataset \\ NMD - National Mapping Division \\ NRCS - Natural Resources Conservation Service \\ NSDI - National Spatial Data Infrastructure \\ NWIS - National Water Information System \\ OMB - Office of Management and Budget \\ RF3 - River Reach File version 3.0 \\ STORET - STOrage and RETrieval \\ TNRCC - Texas Natural Resource Conservation Commission \\ USGS - U.S. Geological Survey
}

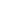

4

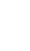

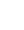

6

8

8

0

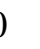
0 12

12

3




\title{
Creating a Standardized Watersheds Database for the Lower Rio Grande/ Río Bravo, Texas
}

\author{
By Julie R. Brown, Randy L. Ulery, and Jean W. Parcher
}

\section{Abstract}

This report describes the creation of a largescale watershed database for the lower Rio Grande/ Río Bravo Basin in Texas. The watershed database includes watersheds delineated to all 1:24,000scale mapped stream confluences and other hydrologically significant points, selected watershed characteristics, and hydrologic derivative datasets.

Computer technology allows generation of preliminary watershed boundaries in a fraction of the time needed for manual methods. This automated process reduces development time and results in quality improvements in watershed boundaries and characteristics. These data can then be compiled in a permanent database, eliminating the time-consuming step of data creation at the beginning of a project and providing a stable base dataset that can give users greater confidence when further subdividing watersheds.

A standardized dataset of watershed characteristics is a valuable contribution to the understanding and management of natural resources. Vertical integration of the input datasets used to automatically generate watershed boundaries is crucial to the success of such an effort. The optimum situation would be to use the digital orthophoto quadrangles as the source of all the input datasets. While the hydrographic data from the digital line graphs can be revised to match the digital orthophoto quadrangles, hypsography data cannot be revised to match the digital orthophoto quadrangles. Revised hydrography from the digital orthophoto quadrangle should be used to create an updated digital elevation model that incorporates the stream channels as revised from the digital orthophoto quadrangle. Computer-generated, standardized watersheds that are vertically integrated with existing digital line graph hydrographic data will continue to be difficult to create until revisions can be made to existing source datasets. Until such time, manual editing will be necessary to make adjustments for man-made features and changes in the natural landscape that are not reflected in the digital elevation model data.

\section{INTRODUCTION}

Watersheds are natural boundaries dividing the land into water-resource management units that often are more useful than other traditional boundaries (for example, political boundaries). Issues such as water quality, water allocation, drought, and flood management, as well as aquatic habitat protection and management all depend on watershed-level data, and watershed boundaries frequently are used in studies dealing with these types of issues. Therefore, it is becoming increasingly desirable to have a comprehensive, standardized, large-scale watershed database for a State and for the Nation. Such a database would avoid duplication of data, and further subdelineation of watersheds would be more consistent with existing watershed boundaries. The following programs demonstrate the need for a large-scale watershed database:

- The U.S. Environmental Protection Agency (EPA) currently emphasizes a watershed-management approach to integrated development, implementation, and enforcement of waterquality protection programs. 
- The Natural Resources Conservation Service (NRCS), U.S. Department of Agriculture, conducts its agricultural support programs for small watershed planning and engineering within a watershed framework.

- The Texas Natural Resource Conservation Commission (TNRCC), as part of its Basin Planning initiative, emphasizes a watershed-based approach to the assessment, management, and protection of river basin water quality in Texas (Texas Natural Resource Conservation Commission, 1994). TNRCC has previously supported development of watershed boundaries and attributes by the U.S. Geological Survey (USGS) at USGS and Clean Rivers Program (CRP) water-quality sampling sites across the State (Tan, 1997).

- Watershed boundaries are a base data layer for the USGS National Water-Quality Assessment (NAWQA) Program, a national study encompassing most of the major river basins or aquifers in the United States. Knowledge of the characteristics of the watershed above a sampling site on a stream is critical to a major NAWQA program goal of establishing cause and effect relations for point- and non-point source water-quality contaminants. NAWQA studies in Texas are making extensive use of watershed boundaries and characteristics.

Numerous other local, State, and Federal agencies, ranging from municipal flood-control districts and river authorities to the U.S. Army Corps of Engineers, implement their water-resources and environmentalprotection programs within a watershed framework.

During 1998-99 a large-scale watershed database was created for the lower Rio Grande/Río Bravo Basin in Texas by the U.S. Geological Survey, in cooperation with the Texas Natural Resource Conservation Commission. The watershed database includes watersheds delineated to all 1:24,000-scale mapped stream conflu- ences and other hydrologically significant points, selected watershed characteristics, and hydrologic derivative datasets.

\section{Purpose and Scope}

The purpose of this report is to:

- Describe an automated procedure for the preliminary delineation of 1:24,000-scale watersheds using USGS digital elevation and hydrographic data as well as Environmental Systems Research Institute (ESRI) Arc/Info ${ }^{\text {TM }}$ GRID software.

- Describe the technical review process needed before the preliminary delineations can be considered representative of the watershed. This includes comparison of the 1:24,000-scale digital line graph (DLG) hydrography to current digital orthophoto quadrangles (DOQs) and revision of these data as needed.

- Describe the attribution of the final watersheds with standard watershed characteristics as recommended in the "National Handbook of Recommended Methods for Water-Data Acquisition" (U.S. Geological Survey, 1978).

- Describe the conflation of the 1:100,000-scale River Reach File version 3.0 (RF3) dataset attributes to 1:24,000-scale DLG hydrography.

- Describe the limitations, lessons learned, and benefits of using an automated process to develop digitally based, large-scale watershed delineations.

The geographic scope of this study included an area of about 2,000 square miles in the lower Rio Grande/Río Bravo Basin in Texas, consisting of Hydrologic Unit Code (HUC) 13090001, HUC 13090002, and the Arroyo Colorado Basin within HUC 12110208 (fig. 1).

Digital datasets created in this study are available over the Internet at http://pubs.water.usgs.gov/ ofr00065.

\section{Acknowledgments}

The authors wish to thank Dana Barbie and Tim Raines, USGS hydrologists, and Roger Miranda, TNRCC, who evaluated the computer-generated, preliminary watershed boundaries. 


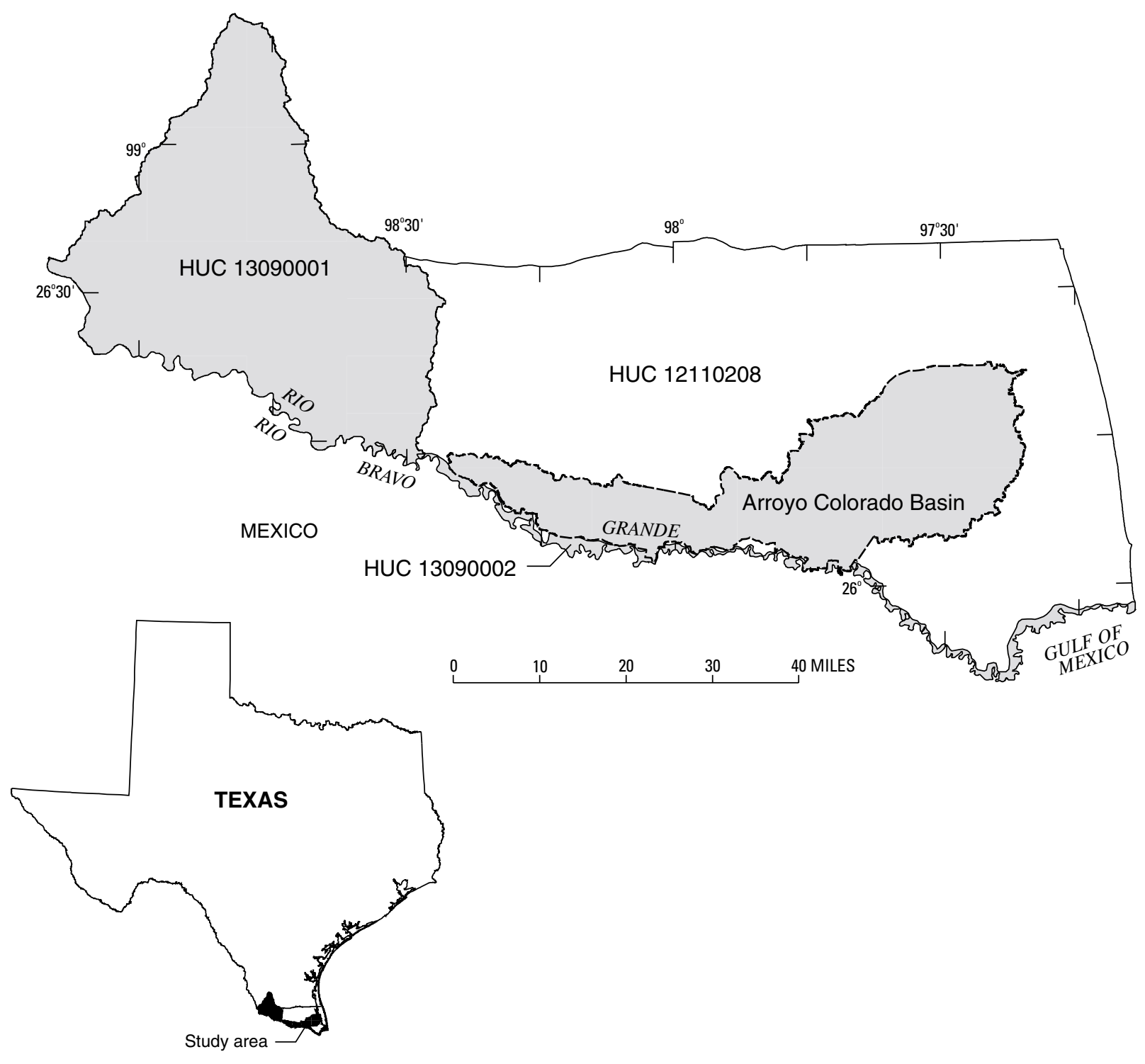

LOCATION MAP

Figure 1. Location of study area.

\section{Background}

\section{Watershed-Boundary Delineation}

Historically, watershed-boundary delineation and mapping has been a labor-intensive activity requiring access to an extensive topographic map library and to ancillary maps and documents. The delineation process requires a visual interpretation of features on the map and, therefore, is somewhat subjective, relying on hydrologic judgement to ensure that the delineated watershed adequately represents the actual watershed. In addition to topographic information and hydrography, ancillary information such as location of roads, bridges, diversions, and impoundments are required to delineate and map watershed boundaries accurately.

The development of watershed boundaries from digital sources using computer software removes much of the subjective nature of the delineated boundary because others using the same datasets can reproduce the same watershed boundary. Using a computer, the 
analyst can delineate watershed boundaries in a fraction of the time needed for traditional hand methods. However, an experienced hydrologist should review the boundaries, and adjustments might be necessary to account for man-made features/alterations or other conditions that are not reflected in the digital elevation model (DEM). The final product optimizes the efficiency of the computer with the judgement of a hydrologist to produce a high-quality delineation of the watershed or parts of watersheds.

Many organizations have needed watershed boundaries but have not had the resources to create them on a national scale. Watersheds have been delineated by various agencies for their particular application or project, using various source and scale maps. For many years the USGS, as part of its mission to provide streamflow and water-quality information, has delineated selected watersheds on paper topographic maps to determine basin characteristics associated with gaging stations or monitoring sites. State and local agencies typically prepare maps and reports that contain watershed boundaries for their particular geographic region of interest. In a few states, the USGS has worked closely with its cooperators at the regional level, particularly in coastal areas of low relief, to delineate large-scale watersheds. Information gathered from large-scale maps is extremely important in the construction of watershed boundaries. In these states with USGS input, the watershed delineations, after thorough review by all interested parties, typically have become the "official" watershed boundaries for the state (Ellis and Price, 1995).

\section{Standardized Watershed Classification}

The USGS, under provisions of the Office of Management and Budget (OMB) (Darman, 1991), has Federal leadership responsibility for overall water-data coordination including custody of the national hydrologic unit maps and development of the HUC system in cooperation with the U.S. Water Resources Council. This system defines an 8-digit standardized coding scheme that serves as a base for the cataloging, indexing, and referencing of hydrologic data (U.S. Geological Survey, 1982). The system divides the United States into a 4-level hierarchy of regions, sub-regions, accounting units, and cataloging-unit-sized drainage areas. Each level of the hierarchy is assigned a 2-digit code. The 2-digit codes can be linked together to yield a unique identifier, therefore each cataloging unit is uniquely identified by an 8-digit numeric code. Intended primarily as a planning tool, the boundaries of the HUC coding system divide the country into 21 regions, 222 sub-regions, 352 accounting units, and 2,149 cataloging units. A HUC includes the contributing drainage to a hydrologically significant point on the stream. Hydrologically significant points include the mouths of major river basins, the reach of a river and the tributaries to that reach, a group of streams forming a coastal drainage area, or a distinct hydrologic feature (for example a major dam or stream confluence). A set of State Hydrologic Unit maps (1:500,000-scale) published by the USGS in 1974 depicted the HUC boundaries. These HUC maps were subsequently modified to create the most comprehensive, digital watershedboundary data layer available on a statewide basis (Seaber and others, 1987). This is the only existing standardized watershed-boundary dataset that extends across state boundaries to encompass all river basins in the United States; however, use of the HUC maps is limited to State, regional, or national applications because of the $1: 250,000$ scale.

HUCs are an accepted national framework for water- and land-resource planning in many states, as well as in the Federal government. The major Federal water-quality databases (STORET and NWIS) are attributed with the HUCs to catalogue and access waterquality data. Currently (1999), cooperative National Spatial Data Infrastructure (NSDI) framework development efforts by the USGS and EPA involve the production of a National Hydrography Dataset (NHD) at the 1:100,000 scale that incorporates the HUC as part of a unique feature identification number assigned to river segments.

Although useful for regional and national planning, the 8-digit HUC does not provide sufficient detail to uniquely identify subsequent larger-scale watersheds. Various methods have been proposed to extend the HUC to 10 digits and then to 12 digits (watershed and subwatershed levels). In recent years the NRCS has led efforts to extend the 8-digit HUC code to an 11-digit code and then a 14-digit code (U.S. Department of Agriculture, 1995). The NRCS also has promoted the development of watershed and sub-watershed mapping and digitizing by doing some delineation of 11-digit HUCs. Some NRCS State offices have been working on 14digit HUC delineation. The USGS currently (1999) is working with other Federal agencies to draft a Federal Geographic Data Committee (FGDC) Thematic Standard for watershed mapping, delineation, digitalization, 
and attribution (Robert Pierce, U.S. Geological Survey, written commun., 1997). This effort will support a nationally consistent method for digital watershed mapping and attribution in the United States and, if adopted, will afford the recognition of watershed boundaries as a national framework dataset that is part of the NSDI (Federal Geographic Data Committee, written commun., 1996).

\section{Watershed Characteristics}

Delineation of the watershed boundary is typically an initial step in the study and management of water resources. As many as 27 key watershed characteristics might be required during routine waterresource investigations. The following selected morphometric watershed characteristics are necessary attributes for many water-resource investigations: contributing drainage area, average slope, maximum and minimum elevation, drainage density, and basin length and width. Many additional watershed or streamflow characteristics could be derived from these attributes.

Selected flow characteristics of the stream can be reasonably estimated from watershed characteristics using statistical techniques. Many watershed hydrologic models require a set of basin characteristics as input variables. Ecological studies and aquatic habitat assessments frequently need basin characteristics; however, these applications typically involve large-scale datasets and large-scale watershed delineations that often are unavailable.

In the past, determination of watershed characteristics has been a labor intensive, time consuming process that is subject to error; the reproducibility of these data also is problematic. With computer technology this process can be automated, resulting in a higher quality product than previously attainable using hand methods. This automated process has a major benefit in addition to reduced development time and quality improvements; the watershed boundaries and characteristics can be pre-determined and placed in a permanent database. This eliminates the often time-consuming step of having to create a watershed database at the initiation of a project. An existing watershed database also provides a stable base dataset that affords users higher confidence when further subdividing watersheds. A standardized dataset of watershed characteristics attributed to the watershed boundary is a valuable contribution to the understanding and management of natural resources.

\section{Topographic Datasets}

Topographic datasets such as flow direction and flow accumulation (also referred to as hydrologic derivative datasets) often are constructed as needed and are used as source datasets for the watershed-delineation process. Each topographic dataset may take several hours of computer time to produce, the datasets then are discarded because of limitations of computer storage. Use of the interim topographic datasets from this report eliminates the need for end users of the database to reproduce the datasets. Subdivision of an existing watershed using a publicly available interim dataset would yield a sub-watershed with boundaries that match the existing standardized watershed delineations, stream segments, and basin characteristics. By using the same source datasets, end users would avoid common problems of edge matching with adjacent watersheds. A long-term benefit is that these base topographic datasets, used in conjunction with the standardized watershed boundaries, make possible an interactive watershed subdelineation capability useful to on-line or Internet-based resource management and assessment systems.

\section{METHODS USED TO CREATE A STANDARDIZED WATERSHEDS DATABASE}

\section{Source Datasets}

Three standard USGS National Mapping Division (NMD) products were used for the watersheddelineation study. These included 3.75-minute DOQs, 7.5-minute DLG hydrography vector data, and a version of the National Elevation Database (NED). The NED is a seamless "best available" DEM for the area. This NED product, with the same resolution as the 7.5-minute DEMs, reduced the amount of time needed to assemble the elevation datasets for the study area.

Each of the mapping products used in this study was produced using source materials with different dates. For example, the aerial photographs used to create the DOQs had a source date of 1995, whereas the topographic maps showing the hydrographic and hypsographic data had earlier source dates from the 1970s and 1980s. Vertical integration of input datasets used to automatically generate watershed boundaries is crucial. Vertical integration between datasets cannot be assured if the source date of materials is different. Taking into consideration the difference between the source dates is 
very important in understanding why some features might be visible in one product (the DOQ, for example) but are not mapped in another product (the hydrographic DLG, for example). The optimum situation would be to use DOQs as the source of all the input datasets. The hydrographic data can be revised to match the DOQ; however, the hypsographic data used to create the DEM cannot be revised to match DOQs. A cartographer needs to view the aerial photographs in stereo to revise the hypsographic contours to create a revised DEM. A method should be selected that uses the revised hydrography from the DOQs to create a DEM that matches the newer stream channels as interpreted from the DOQ. The hypsographic data do not have to be revised because elements of the revised hydrography can be integrated into the hypsographic data before gridding the DEM. Creation of a higher resolution (5 to 10 meters) DEM that better matches the revised hydrography from the DOQ could help create a higher quality watershed dataset.

The DOQs are digital images of aerial photographs in which displacements caused by the camera and the terrain have been removed. DOQs combine the image characteristics of a photograph with the geometric qualities of a map, and they serve a variety of purposes from interim maps to field references for earthscience investigations and analyses. DOQs also are useful as a tool for the revision of DLGs and topographic maps. The source of the aerial photographs used to create the DOQs in the study area include color infrared (CIR) photography taken during the winters of 1995 and 1996. The aerial photography was taken at 20,000 feet with a scale of 1:40,000. Information about the exact date of the photography used to create the DOQ can be found in the keyword header, which is the text information found at the beginning of the DOQ file available from NMD.

DLG data files are digital representations of cartographic information in vector format. Data files of topographic and planimetric map features are derived from aerial photographs or cartographic source materials using manual and automated digitizing methods. The hydrographic DLGs for the study area were derived from topographic maps with original source dates from 1969 to 1980 . The source of the DLG data can be found in the beginning lines of the DLG file available from NMD. The source date of the materials used to create the vector data can be found on line 2 of the DLG file.
As DOQs become available for a given area, NMD will use the DOQs as a source for producing and/or revising DLG data.

DEM data files are digital representations of cartographic information in raster form. DEMs consist of a sampled array of elevations for ground positions at regularly spaced horizontal intervals. The DEMs used for this project were based on a $30 \times 30$-meter data spacing interval with the Universal Transverse Mercator projection. The source materials used to create the DEMs included an interpolation of the DLG hypsographic data derived from topographic maps. A $30 \times 30$-meter data spacing version of the NED was used for this study. The NED is a seamless, multi-source, elevation database compiled from the "best" available DEM data. The processes involved in production of the NED include filtering production artifacts, computing datum conversions, appending individual DEM files, computing coordinate transformations, resampling data, merging the various sources, and performing edge matching to create the baseline NED. For analysis of elevation and terrain data over an area larger than one USGS quadrangle map, the NED is the preferable source.

The creation of a computer-generated, standardized, watershed dataset that is vertically integrated with existing hydrography will continue to be difficult until revisions can be made to existing source datasets. Until such time, manual delineation will be necessary to make adjustments for man-made features and changes in the natural landscape that are not reflected in the digital elevation data.

\section{DEM Processing-Creation of Hydrologic Derivatives}

The NED data were acquired and processed to produce the necessary hydrologic derivative datasets used to delineate preliminary watersheds and compute watershed characteristics. The initial NED elevation grid contained floating point data, which were converted to integer data to reduce file size and to reduce processing times. Sinks then were removed from the elevation grid to produce a depressionless surface. Sinks are areas that water flows into but cannot flow out of and can cause problems when creating hydrologic derivative datasets. Many sinks are errors in the data, and the challenge is to remove the errors but retain any natural sinks. Sinks were removed with the FILL command in the Arc/Info ${ }^{\text {TM }}$ GRID module using a threshold, or z-limit, to set the maximum depth of a sink to be filled. A z-limit 


\begin{tabular}{|l|l|l|l|l|l|}
\hline 78 & 72 & 69 & 71 & 58 & 49 \\
\hline 74 & 67 & 56 & 49 & 46 & 50 \\
\hline 69 & 53 & 44 & 37 & 38 & 48 \\
\hline 64 & 58 & 55 & 22 & 31 & 24 \\
\hline 68 & 61 & 47 & 21 & 16 & 19 \\
\hline 74 & 53 & 34 & 12 & 11 & 12 \\
\hline
\end{tabular}

Elevation

\begin{tabular}{|c|c|c|c|c|c|}
\hline 2 & 2 & 2 & 4 & 4 & 8 \\
\hline 2 & 2 & 2 & 4 & 4 & 8 \\
\hline 1 & 1 & 2 & 4 & 8 & 4 \\
\hline 128 & 128 & 1 & 2 & 4 & 8 \\
\hline 2 & 2 & 1 & 4 & 4 & 4 \\
\hline 1 & 1 & 1 & 1 & 4 & 16 \\
\hline
\end{tabular}

\begin{tabular}{|c|c|c|}
\hline 32 & 64 & 128 \\
\hline 16 & 4 & 1 \\
\hline 8 & 4 & 2 \\
\hline
\end{tabular}

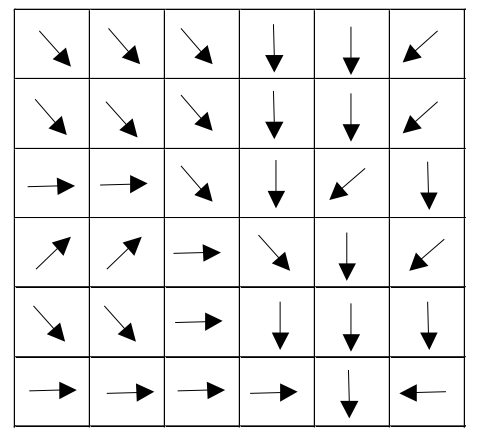

Flow direction

Figure 2. Flow-direction grid (modified from Environmental Systems Research Institute, 1997).

of 5 meters was used to fill the elevation grid, based on research suggesting that sinks greater than 4.8 meters in a 7.5-minute DEM are usually real (Tarboton and others, 1991). The resulting elevation grid was free of sinks. However, because detailed maps of real sinks are not available for Texas, it is possible that some real sinks might have been filled.

The next step in the process was to create hydrologic derivative datasets, grids of flow direction and flow accumulation that are used to delineate watersheds. Watersheds are delineated using the flowdirection grid to find all cells that flow to an outlet or pour point. The flow-direction grid was created using the FLOWDIRECTION function in the Arc/Info ${ }^{\text {TM }}$ GRID module. The flow-direction grid (fig. 2) contains cell values indicating the direction water would flow out of each cell based on elevation. For each cell in the elevation grid, the direction of flow out of each cell is determined, and the value is assigned to the flowdirection grid. Eight valid output directions are available, relating to the eight-cell neighborhood surrounding the cell (Environmental Systems Research Institute, Inc., 1992).
The flow-accumulation grid was used to derive a synthetic stream network, which was used to place outlet or pour points for the watershed delineations. In the flow-accumulation grid, cell values indicate how many other cells flow into them based on flow direction (fig. 3). The FLOWACCUMULATION function in the Arc/Info ${ }^{\text {TM }}$ GRID module was used to generate the flowaccumulation grid.

A synthetic stream network was derived from the flow-accumulation grid by identifying cells with high flow-accumulation values. This grid was eventually used to locate outlet or pour points from which the preliminary watershed boundaries were computer generated and from which the watershed stream characteristics were calculated. After comparing the resulting grids created using threshold values of 100 , 250 , and 500 to the revised 1:24,000-scale hydrography data layer, a threshold of 250 cells was chosen. This threshold value sets the minimum stream length at 339 meters, which generates a network very similar to the revised hydrography. A stream network was 


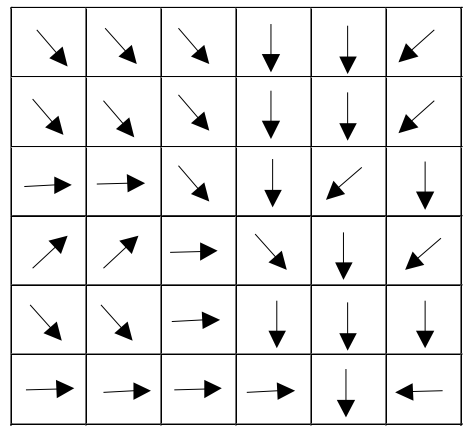

Flow direction

\begin{tabular}{|c|c|c|c|c|c|}
\hline 0 & 0 & 0 & 0 & 0 & 0 \\
\hline 0 & 1 & 1 & 2 & 2 & 0 \\
\hline 0 & 3 & 7 & 5 & 4 & 0 \\
\hline 0 & 0 & 0 & 20 & 0 & 1 \\
\hline 0 & 0 & 0 & 1 & 24 & 0 \\
\hline 0 & 2 & 4 & 7 & 35 & 2 \\
\hline
\end{tabular}

Flow accumulation

Figure 3. Flow-accumulation grid (modified from Environmental Systems Research Institute, 1997).

produced for the study area using the grid function, SETNULL and GRID algebra:

Streamnet $=$ SETNULL $($ Flowacc $\leq 250,1)$,

where

Streamnet $=$ stream network and

Flowacc $=$ flow-accumulation grid

Cells in the flow-accumulation grid greater than 250 were assigned a value of 1 in the output grid so that all cells with data in the output grid represent the synthetic stream network (fig. 4). All cells in the flowaccumulation grid less than or equal to 250 were assigned NODATA in the output grid. The synthetic stream network facilitated locating appropriate grid cells from which to delineate preliminary watersheds.

\section{Watershed Delineation}

Using the Arc/Info ${ }^{\text {TM }}$ GRID module and hydrologic derivative datasets, preliminary watershed boundaries can be delineated automatically at an outlet or pour point. Using the stream network grid that was created with the flow-accumulation grid and the revised 1:24,000-scale hydrography as background references, points were created at all mapped stream confluences and other hydrologically significant points. Preliminary watersheds were delineated to all of the outlet points using the WATERSHED function in GRID.

Because of low relief in coastal parts of the study area and poor quality of initial watershed boundaries in these areas, additional processing of the DEM was attempted. Different methods can be used to hydrologically "correct" digital elevation data using hydrologic datasets. These methods use vector stream data to force the surface to properly delineate the location of the stream. Two of these methods, TOPOGRID and AGREE, were used to further process the DEM for this project. TOPOGRID is an $\mathrm{Arc} / \mathrm{Info}^{\mathrm{TM}}$ command using a number of parameters and inputs to create a new, hydrologically correct DEM, and AGREE ${ }^{\mathrm{TM}}$ is a surface reconditioning Arc Macro Language (AML) program developed at the University of Texas (Center for Research in Water Resources, 1997). After attempts were made using both methods, no improvement was evident in the resulting DEMs compared to the original dataset. Manual delineation of sub-watersheds yielded more desirable results in the coastal areas.

\section{Revision of the Hydrography}

The 1:24,000-scale DLG hydrography was inspected to verify vertical integration with the most recent (1995-96) digital orthoimagery source material. Differences were observed between features in the orthoimagery and in the existing DLG hydrography lines. In some cases, DLG features were not present at all in the orthoimagery, or the DLG hydrography lines were shifted as far as 75 meters from observed features in the orthoimagery. Furthermore, hydrography was shifted by varying amounts across the imagery. The exact cause of this inconsistency was not determined. However, the source used to create the hydrography DLG was different from the source used to create the DOQs. Some of the inconsistencies in the location of the stream lines in the Arroyo Colorado between the orthophoto images and DLG features were caused by extensive man-made influences (for example, elevated irrigation canals and urbanization) that have occurred since the most recent revision of the DLG hydrography. 


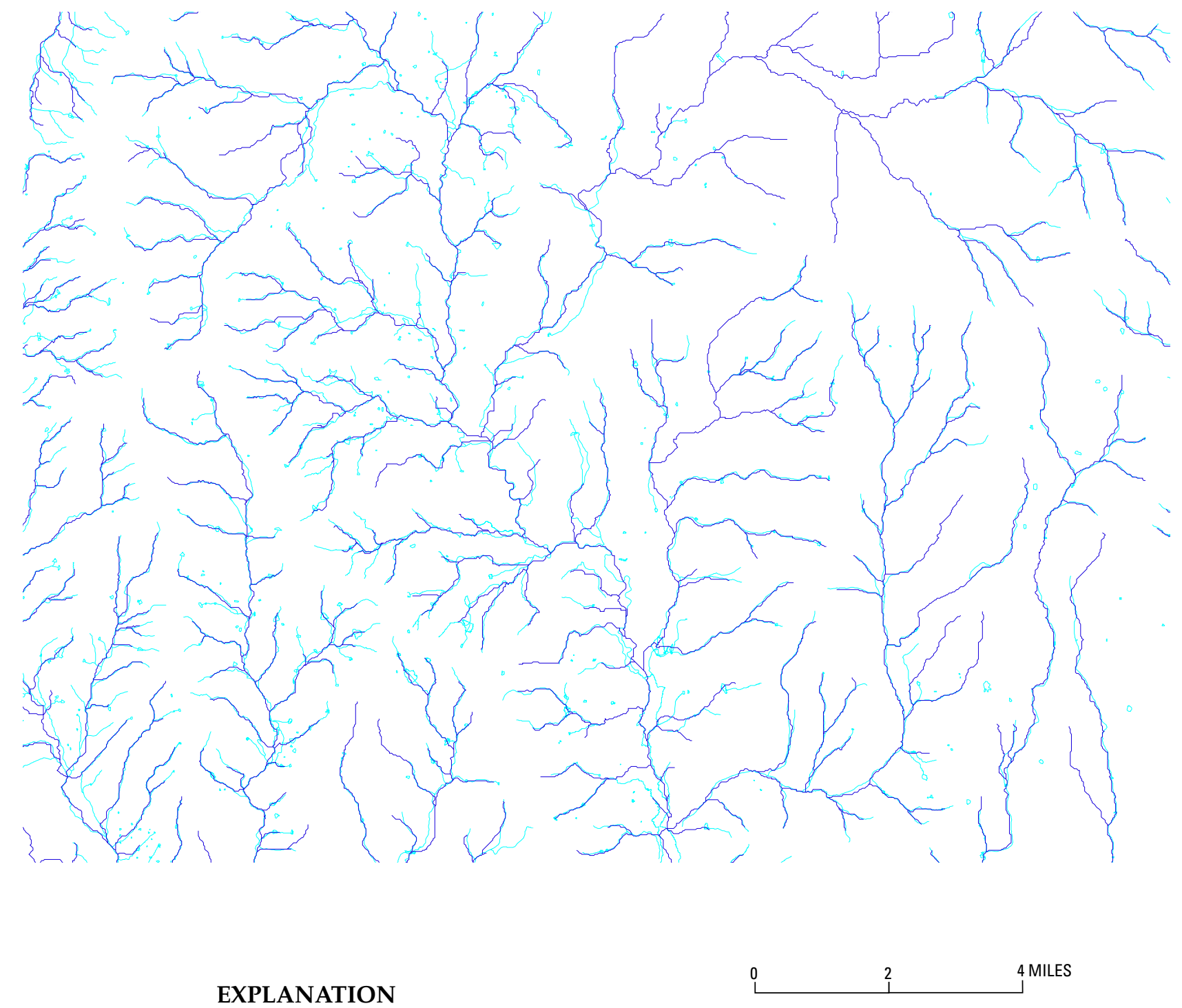

Synthetic stream network

1:24,000 digital line graph hydrography

Figure 4. Stream network derived from flow-accumulation grid.

Natural changes in the channel of the Rio Grande also have occurred that are not reflected in the current DLG data. Because of these differences, hydrography was revised for the Arroyo Colorado and along the main stem of the Rio Grande. In the Arroyo Colorado area, hydrography, topographic maps, and existing basin boundary maps were critical in manually delineating most of the watersheds. HUC13090002 was entirely hand delineated because of insufficient resolution in the DEM, which inhibited recognition of drainage patterns along the Rio Grande near the Gulf of Mexico.

\section{Computer-Generated Watershed Delineations}

The Arc/Info ${ }^{\text {TM }}$ GRID module has a

WATERSHED function that uses a flow-direction grid 
and an outlet or pour point (or a grid of outlet points) to delineate watersheds. The function is:

Outgrid = WATERSHED(flow_dir, outletptgrid)

Outgrid is the user defined name given to the newly created grid of watersheds, flow_dir is the flowdirection grid, and outletptgrid is a grid containing cells that represent outlet or pour points from which to delineate watersheds. A polygon coverage then was created by vectorizing the watershed grid using the GRIDPOLY function.

\section{Review of Computer-Generated Watershed Delineations and Manual Delineations}

Automated methods of delineating watersheds commonly create very good preliminary results in areas of moderate to high relief; however, careful review is necessary for the final delineation. In areas of low relief, the DEM usually does not accurately delineate true watershed boundaries. Man-made structures on the landscape, which are not reflected in the hydrologic derivative datasets, also can result in inaccurate watershed boundaries.

Upon inspection of the computer-generated watersheds, many watershed boundaries were modified manually. Computer-generated watersheds were compared to USGS hand-delineated watersheds and to elevation contours on 7.5-minute topographic maps. The computer-generated watersheds then were compared to current digital orthoimagery and to revised hydrography to identify any adjustments needed for man-made features. Resulting delineations were digitized and added to the vector watershed coverage.

\section{Watershed Region Coverage}

More than 1,400 large-scale watersheds were delineated at stream confluences and hydrologically significant points. Watersheds were placed in a polygon region coverage containing watershed boundaries, and characteristics were attributed for individual watershed boundaries. The normal polygon data model in Arc/Info ${ }^{\mathrm{TM}}$ does not support nested polygons; therefore, the Arc/Info ${ }^{\text {TM }}$ REGION data model was used to maintain the integrity of each individual watershed within one coverage. Each 8-digit HUC makes up a region, and attributes for each watershed (polygon) within the region are stored in region attribute tables. An additional attribute table, the RXP table, maintains the relations between the sub-watersheds and watersheds with regions being stored as lists of polygons and arcs (Environmental Systems Research Institute, 1995).

\section{Watershed Characteristics}

Watersheds in HUC13090001 and the Arroyo Colorado in HUC12110208 were attributed with standard watershed characteristics as recommended in the "National Handbook of Recommended Methods for Water-Data Acquisition" (U.S. Geological Survey, 1978). Watershed characteristics are listed in table 1.

An automated process was developed to calculate watershed characteristics using the Arc/Info ${ }^{\text {TM }}$ GRID module and AML. The program used the watershed region coverage to iteratively process each watershed and create temporary datasets to be used in the calculations. Temporary datasets included grids of the pour point and watershed, synthetic hydrography, and vector coverages of the synthetic stream network and water bodies. Methods used to quantify watershed characteristics were modified from those used in the USGS software BASINSOFT (Harvey and Eash, 1996). According to Harvey and Eash (1996, p. 11), statistical tests showed that results obtained using these methods were not significantly different $(p>0.05)$ from manual methods for 9 of 10 characteristics. Watershed characteristics calculated in this study were compared with results using BASINSOFT for two basins (Douglas Freehafer, U.S. Geological Survey, written commun., 1999). Results of the comparison showed a less than 3 -percent difference in results for 26 of 29 characteristics. Differences in calculation of first-order streams, drainage frequency, and relative stream density were larger, possibly because of the threshold values used to derive synthetic stream networks. Basin stream order was identical for both methods. Watershed characteristic computations are listed in the appendix.

Watershed characteristics were not determined for HUC13090002 because the watershed boundary was entirely hand digitized from existing basin boundary maps and digital orthoimagery, and therefore, the automated process of determining watershed characteristics could not be applied.

\section{Conflation of RF3 Attributes}

Conflation of attributes from the 1:100,000-scale NHD to the 1:24,000-scale DLG hydrography was an initial objective of this project. Conflation is used to transfer attributes from one dataset to corresponding features in another dataset, often moving attributes from 
Table 1. Watershed characteristics or classification codes

[--, none or not applicable]

\begin{tabular}{|c|c|c|}
\hline Characteristic & Abbreviation & Unit \\
\hline Total drainage area & TDA & Square miles \\
\hline Non-contributing area & NCA & Square miles \\
\hline Contributing drainage area & CDA & Square miles \\
\hline Basin length & BLENG & Miles \\
\hline Basin perimeter & $\mathrm{BP}$ & Miles \\
\hline Average basin slope & BS & Feet per mile \\
\hline Basin relief & $\mathrm{BR}$ & Feet \\
\hline Minimum basin elevation & MNELEV & Feet \\
\hline Maximum basin elevation & MXELEV & Feet \\
\hline Average basin elevation & AVELEV & Feet \\
\hline Basin azimuth & $\mathrm{BA}$ & Degrees \\
\hline Effective basin width & BW & Miles \\
\hline Basin shape factor & $\mathrm{SF}$ & -- \\
\hline Elongation ratio & ER & -- \\
\hline Rotundity of basin & $\mathrm{RB}$ & -- \\
\hline Compactness ratio & $\mathrm{CR}$ & -- \\
\hline Relative relief & $\mathrm{RR}$ & Feet per mile \\
\hline Main channel length & MCL & Miles \\
\hline Total stream length & TSL & Miles \\
\hline Main channel slope & MCS & Feet/mile \\
\hline Main channel sinuosity ratio & MCSR & -- \\
\hline Drainage density & $\mathrm{DD}$ & Miles per square mile \\
\hline Constant of channel maintenance & $\mathrm{CCM}$ & Square miles per mile \\
\hline Main channel slope proportion & MCSP & -- \\
\hline Ruggedness number & $\mathrm{RN}$ & Feet per mile \\
\hline Basin storage & STO & Square miles \\
\hline Slope ratio of main channel slope to basin slope & SR & -- \\
\hline Number of first-order streams using Strahler method & FOS & Number of FOS \\
\hline Basin stream order & BSO & Order number \\
\hline Drainage frequency & DF & Number of FOS per square mile \\
\hline Relative stream density & RSD & -- \\
\hline 8-digit hydrologic unit code & HUC & HUC \\
\hline Region (2) & REG & -- \\
\hline Sub-region (2) & SUB & -- \\
\hline Accounting unit (2) & ACC & -- \\
\hline Cataloging unit (2) & CAT & -- \\
\hline
\end{tabular}


a highly generalized to a more detailed set of features. The NHD is a merger of the EPA River Reach File version 3.0 (RF3) and the USGS DLG hydrography data. A decision was made to transfer attributes from the existing RF3 datasets because the NHD was not yet available. The NHD has additional attributes that will uniquely identify each feature and will have a method for incorporating new features.

Many attributes included in the RF3 data did not transfer, as the RF3 data is a smaller-scale dataset and did not contain all of the streams included in the largerscale revised hydrography. The TRANSFER commands in the Arc/Info ${ }^{T M}$ ARCEDIT module were used to transfer attributes interactively from the RF3 streams to the corresponding streams in the hydrography dataset.

\section{Extending Hydrologic Unit Code (HUC) to 12 Digits}

Another original objective of this study was to extend the 8-digit HUCs in the study area to 10 - or 12 digit HUCs. This task could not be completed because the FGDC standards for this procedure have not been finalized. Additionally, the NRCS is actively subdelineating HUCs. Their work will be incorporated at a future date.

\section{CONCLUSIONS}

This report describes the creation of a large-scale watershed database for the lower Rio Grande/Río Bravo Basin in Texas. The watershed database includes watersheds delineated to all 1:24,000-scale mapped stream confluences and other hydrologically significant points, selected watershed characteristics, and hydrologic derivative datasets.

Historically, watershed-boundary delineation and mapping has been a labor-intensive activity, requiring visual interpretation of features on the map. The manual delineation process is somewhat subjective, relying on hydrologic judgement to ensure an accurate representation of the watershed. Computer technology allows the process of delineating watersheds to be automated, resulting in a higher quality product than previously attainable using hand methods. Reduction in development time is achieved, and watershed boundaries and characteristics can be compiled in a permanent database, eliminating the need to re-create the data for future projects. An existing watershed database also provides a stable base dataset, which gives users greater confidence when further subdividing watersheds.
An automated procedure was used to generate watershed boundaries using hydrologic derivative datasets created from 30-meter digital elevation data and Arc/Info ${ }^{\text {TM }}$ GRID software version 7.2.1. After careful review of the computer-generated boundaries, revisions were made to correct for man-made features in the landscape, such as roads and elevated irrigation channels that were not reflected in the digital elevation data (also referred to as DEMs). The elevation datasets did not reflect the most recent changes in the landscape and, therefore, did not always match the current hydrography as interpreted from digital orthoimagery. Watersheds near the Gulf of Mexico, where topography had little relief, were corrected. Evaluation of hydrologic derivative datasets did not reveal drainage patterns in these areas. The most recent (1995-96) source material from 3.75-minute (1:12,000-scale) DOQs was used in addition to existing basin boundary maps and topographic maps to review and correct the computergenerated watershed boundaries.

A standardized dataset of watershed characteristics is a valuable contribution to the understanding and management of natural resources. Vertical integration of the input datasets used to automatically generate watershed boundaries is crucial to the success of such an effort. The optimum situation would be to use digital orthophotos as the source of all the input datasets. The DLG hydrography data can be revised to match the digital orthophotos, but hypsography data, used as the source of the DEM cannot be interpreted from the digital orthophotos. A method should be chosen that uses hydrography revised from digital orthophotos to create a DEM that matches the newer stream channels as interpreted from the digital orthophoto. The hypsographic data does not have to be revised, as elements of the revised hydrography can be integrated into the hypsographic data before gridding the digital elevation data. Creation of a higher resolution (5 to 10 meters) DEM that better matches the revised hydrography from the digital orthophotos could help create a higher quality watershed dataset.

The creation of a computer-generated, standardized, watershed dataset that is vertically integrated with existing hydrography will continue to be difficult until revisions can be made to existing source datasets. Until such time, manual delineation will be necessary to make adjustments due to man-made features and changes in the natural landscape that are not reflected in the digital elevation data. 


\section{SELECTED REFERENCES}

Center for Research in Water Resources, 1997, AGREE-DEM surface reconditioning system: Austin, University of Texas, accessed Jan. 26, 2000, at URL http://www.ce.utexas.edu/prof/maidment/ gishydro/ferdi/research/agree/agree.html

Darman, Richard, 1991, Coordination of water resources information: Office of Management and Budget Memorandum, M-92-01.

Elassal, A.A., and Caruso, V.M., 1983, USGS digital cartographic data standards-Digital elevation models: U.S. Geological Survey Circular 895-B, $40 \mathrm{p}$.

Ellis, W.H., and Price, C.V., 1995, Development of a 14-digit hydrologic coding scheme and boundary data set for New Jersey: U.S. Geological Survey Water-Resources Investigations Report 95-4134, 1 sheet.

Environmental Systems Research Institute, Inc., 1992, Cell-based modeling with grid 6.1: Redlands, Calif., p. 309-327. 1995, Data conversion and regions: Redlands, Calif. [variously paged]. 1997, Using ARC GRID with ARC/INFO, v. 2: Redlands, Calif., p. 7.4-7.33.

Harvey, C.A., and Eash, D.A., 1996, Description, instructions, and verification for BASINSOFT, a computer program to quantify drainage-basin characteristics: U.S. Geological Survey WaterResources Investigations Report 95-4287, 28 p.
Seaber, P.R., Kapinos, F.P., and Knapp, G.L., 1987, Hydrologic unit maps: U.S. Geological Survey Water-Supply Paper 2294, 63 p.

Tan, L.L., 1997, Topographic data sets for Texas by river basin: U.S. Geological Survey Open-File Report 97-354, 1 compact disc.

Tarboton, D.G., Bras, R.L., and Rodriguez-Iturbe, Ignacio, 1991, On the extraction of channel networks from digital elevation data: Hydrologic Processes, v. 5, p. 81-100.

Texas Natural Resource Conservation Commission, 1994, Basin planning initiative-Geographic unit alternatives for watershed planning and management: Texas Natural Resource Conservation Commission, $51 \mathrm{p}$.

U.S. Department of Agriculture, 1995, Mapping and digitizing watershed and subwatershed hydrologic unit boundaries: Natural Resources Conservation Service National Instruction No. 170-304 [working draft], $41 \mathrm{p}$.

U.S. Geological Survey, 1978, Physical basin characteristics for hydrologic analysis, in National handbook of recommended methods for water-data acquisition: U.S. Geological Survey, Office of Water Data Coordination, chap. 7, 38 p. 1982, A U.S. Geological Survey data standard-Codes for the identification of hydrologic units in the United States and the Caribbean outlying areas: U.S. Geological Survey Circular 878-A, 115 p. 


\section{APPENDIX A- Watershed Characteristic Computations}




\section{Basin-Area Computations:}

Total drainage area (TDA): The ZONALAREA function in GRID was used to determine area for the watershed.

Non-contributing drainage area (NCA): Non-contributing areas were considered to be SINKS in the elevation grid. There were no known sinks in the study area, therefore NCA was always 0 for the purposes of this study.

Contributing drainage area (CDA): TDA - NCA

Basin-Length Computations:

Basin length (BLENG): Using COSTPATH and COSTDISTANCE functions in GRID, a centerline was determined that ran from an outlet to a point where the longest flowpath met the basin divide. The length of the resulting centerline was used for the basin length.

Basin perimeter (BP): Determined from the PERIMETER item in the INFO file of the watershed polygon coverage.

\section{Basin-Relief Computations:}

Average basin slope (BS): The contour-band method was used to determine average basin slope in feet per mile.

$\mathrm{BS}=($ total length of all selected elevation contours) (contour interval) / CDA

Basin relief (BR): Measured as the difference between the highest cell value in the elevation grid of the basin and the elevation of the grid cell at the outlet.

Minimum basin elevation (MNELEV): Taken from statistics INFO file of the elevation grid.

Maximum basin elevation (MXELEV): Taken from statistics INFO file of the elevation grid.

Average basin elevation (AVELEV): Taken from statistics INFO file of the elevation grid.

\section{Basin-Aspect Computations:}

Basin azimuth (BA): Using the GRID function EUCLIDEAN DIRECTION, azimuth was computed from the point on the basin divide where the main channel extended to meet it, to the basin outlet measured clockwise from the source cell at 0 degrees.

\section{Basin Computations:}

Effective basin width (BW): BW = CDA / BLENG

Basin shape factor $(\mathrm{SF}): \mathrm{SF}=\mathrm{BLENG} / \mathrm{BW}$

Elongation ratio $(\mathbf{E R}): \mathrm{ER}=\left[4 \mathrm{CDA} / \mathrm{pi}(\mathrm{BLENG})^{2}\right]^{0.5}=1.13(1 / \mathrm{SF})^{0.5}$

Rotundity of basin $(\mathbf{R B}): \mathrm{RB}=\left[\mathrm{pi}(\mathrm{BLENG})^{2}\right] /[4 \mathrm{CDA}]=0.785 \mathrm{SF}$

Compactness ratio $(\mathbf{C R}): \mathrm{CR}=\mathrm{BP} / 2(\text { pi CDA })^{0.5}$

Relative relief $(\mathbf{R R}): \mathrm{RR}=\mathrm{BR} / \mathrm{BP}$

\section{Channel- or Stream-Length Computations:}

Main channel length (MCL): Computed using the FLOWLENGTH function in GRID to measure the longest flowpath from the pour point to the basin divide.

Total stream length (TSL): Computed by summing the INFO item LENGTH in the hydrography coverage for all the stream segments in the basin.

\section{Channel-Relief Computations:}

Main channel slope (MCS): Computed from the difference in the elevations at 10 percent $\left(\mathrm{E}_{10}\right)$ and 85 percent $\left(\mathrm{E}_{85}\right)$ of the distance along the main channel from the pour point to the basin divide.

$\operatorname{MCS}=\left(\mathrm{E}_{85}-\mathrm{E}_{10}\right) / 0.75(\mathrm{MCL})$ 


\section{Channel or Stream Computations:}

Main channel sinuosity ratio (MCSR): MCSR = MCL / BL

Drainage density (DD): DD = TSL / CDA

Constant of channel maintenance $(\mathbf{C C M}): \mathrm{CCM}=\mathrm{CDA} / \mathrm{TSL}=1 / \mathrm{DD}$

Main channel slope proportion $(\mathrm{MCSP}): \mathrm{MCSP}=\mathrm{MCL} /(\mathrm{MCS})^{0.5}$

Ruggedness number $(\mathbf{R N}): \mathrm{RN}=(\mathrm{TSL})(\mathrm{BR}) / \mathrm{CDA}=(\mathrm{DD})(\mathrm{BR})$

Basin storage (STO): Computed by summing the INFO item AREA in the basin hydrography polygon coverage for all storage polygons in the basin.

Slope ratio of main channel slope to basin slope (SR): SR = MCS / BS

\section{Stream-Order Computations:}

Number of first-order streams (FOS): A stream-order grid was created using the Strahler method option in GRID. GRID summary statistics are used to compute the number of first-order streams.

Basin stream order (BSO): Stream order of the main channel at the basin outlet.

Drainage frequency $(\mathrm{DF}): \mathrm{DF}=\mathrm{FOS} / \mathrm{CDA}$

Relative stream density (RSD): $\mathrm{RSD}=(\mathrm{FOS})(\mathrm{CDA}) /(\mathrm{TSL})^{2}=\mathrm{DF} /(\mathrm{SD})^{2}$ 


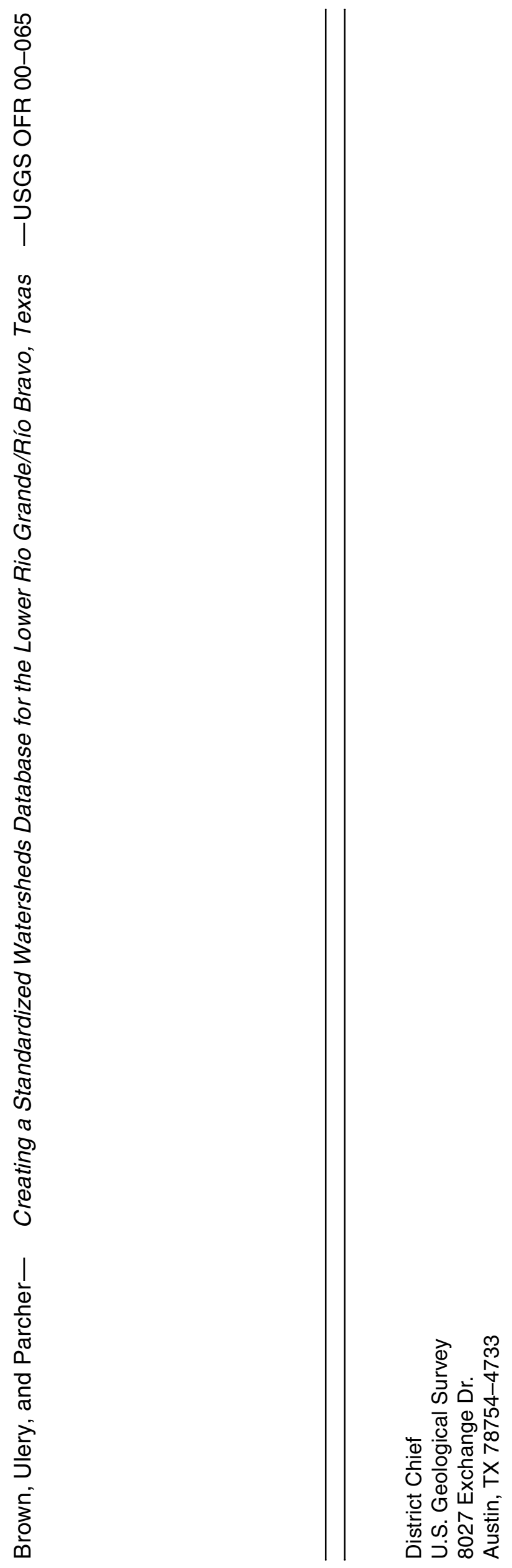

